\title{
Seed developmental and maturation studies in davana (Artemisia pallens)
}

\author{
${ }^{* 1}$ M.Jayanthi, ${ }^{2}$ A.Vijayakumar, ${ }^{3}$ K.Vanangamudi and ${ }^{4}$ K.Rajamani. \\ ${ }^{1}$ Department of Seed Science and Technology, Adhiparasakthi Agricultural, Horticultural College and Research \\ Institute, G.B.Nagar, Kalavai, Vellore, ${ }^{2,3}$ Department of Seed Science and Technology and ${ }^{4}$ Department of \\ Medicinal and Aromatic crops, TamilNadu Agricultural University, Coimbatore.
}

\begin{abstract}
Davana (Artemisia pallens) ia an important high valued annual medicinal and aromatic herb of India belonging to the family Asteraceae. India has a monopoly in production and export trade of davana oil and India stands $3^{\text {rd }}$ in essential oil production in the world. This study was conducted at Department of seed science and technology, TamilNadu Agricultural University, Coimbatore to determine the seed developmental and maturation studies in davana. The bulk davana crop was raised in the field. Individual flower heads were tagged at the time of flower opening. The seeds were collected at 5 days intervals and subjected to the following seed quality assessment. The observation made on seed moisture content (\%), 1000 seed weight (mg), germination \%, seedling length $(\mathrm{cm})$, dry matter production and vigour index. The results revealed that physiological maturity of davana seeds was attained on $35^{\text {th }}$ day after anthesis, where in germination percentage (86), seedling length (2.3), vigour Index (198) and dry matter production (1.23mg) were higher.
\end{abstract}

Keywords: Davana, seed development and maturation, germination \%, seedling length, drymatter production, vigour index.

\section{Introduction:}

Aromatic plants are the natural source of perfumes and fragrance widely exploited by essential oil industries across the world. India stands $3^{\text {rd }}$ in essential oil production in the world, the first being France while Britain takes the $2^{\text {nd }}$ place. Davana (Artemisia pallens) is an important high valued annual aromatic herb of India belonging to the family Asteraceae and commercially cultivated in south India as a short duration crop from November to march. India has a monopoly in production and export trade of davana oil and India stands $3^{\text {rd }}$ in essential oil production in the world. Davana is traditionally used in religious ceremonies and in making garlands, bouquets, floral decorations and floral chaplets, lends an element of freshness and a rich sumptuousness of fragrance to religious occasions (Narayana et al., 1998) [1]. The essential oil of davana extracted from air dried flowering herb, is a brown viscous liquid with deep mellow, persistent, rich fruity odour and it is recognized as one of the most useful essential oils for formulating natural flavours that are used in cakes, pastrics, beverages in United States of America, Europe and Japan (Pisana 1989) [2]. Artemesia pallens possesses anti-inflammatory, antipyretic and analgesic propertiesit is used in Indian folk medicine for the treatment of Diabetes mellitus. (Al-Harbi et al., 1994) [3]. Seed maturity is the crucial and most important factor determining the seed quality under successful seed production programme (Austin, 1972) [4]. It is understood that seed maturation is the gradual preparation for germination (Bewley and Black, 1994) [5]. The development process during seed growth and maturity interacts with the production environment to determine the planting quality of a seed. It is well established that seed quality is the highest at physiological maturity which precedes harvestable maturity. This practice would permit quick harvesting at appropriate timings, resulting in better field management (Delouche, 1973)[6]. Hence, knowledge on development of seed from fertilization to maturity is highly warranted.

\section{Materials and methods:}

The study was conducted with davana seeds obtained from Horticultural college and Research Institute, Periyakulam formed the base material for this study. The experiment was conducted at Department of seed science and technology, TamilNadu Agricultural University, Coimbatore to determine the physiological and harvestable maturity status of the seed. The bulk davana crop was raised in the field. Individual flower heads were tagged at the time of flower opening. The seeds were collected at 5 days intervals and subjected to the following seed quality assessment. Seed moisture content, 1000 seed weight, Germination percentage, seedling length, drymatter production and vigour index are the observations recorded. Seed moisture content estimated by the following method. In each developmental stage four replicates of hundred seeds each were weighed $\left(\mathrm{M}_{1}\right)$. The seeds were shade dried followed by oven drying in a hot air oven maintained at $103 \pm 2^{\circ} \mathrm{C}$ for $17 \mathrm{~h}$ and then the seeds were cooled in desiccator with calcium carbonate for $30 \mathrm{~min}$. and the dry weight was taken in an 
electronic balance $\left(\mathrm{M}_{2}\right)$. Adopting the following formula the seed moisture content was calculated and the mean expressed as percentage.

$$
\text { Moisture content }(\%)=\frac{M_{1}-M_{2}}{M_{1}}
$$

Where, $\mathrm{M}_{1}=$ Weight of the sample before drying, $\mathrm{M}_{2}=$ Weight of the sample after drying

For 1000 seed weight, the freshly harvested seed were counted in eight replications of 1000 seeds each, weighed in precision balance and mean weight was recorded in mg. Germination Percentage (ISTA, 1999) [7],The germination test was carried out as per the procedure prescribed by ISTA with four replicates of 100 seeds each in roll towel medium. The test conditions of $25 \pm 2^{\circ} \mathrm{C}$ and $95 \pm 3$ per cent RH were maintained in a germination room illuminated with fluorescent light. After eight days, the normal seedlings produced were counted and expressed as percentage. Seedling length $(\mathrm{cm})$, Ten normal seedlings were selected at random from each replication and the seedling length was measured from the tip of primary root to the tip of the primary leaf and expressed in $\mathrm{cm}$. Drymatter production $\left(\mathrm{mg}\right.$ seedlings $\left.{ }^{-10}\right)$, Randomly selected ten normal seedlings used for seedling measurements were dried under shade for $24 \mathrm{~h}$ and then dried in hot air oven maintained at $85 \pm 1^{\circ} \mathrm{C}$ for $48 \mathrm{~h}$. It was cooled in a desiccator for $30 \mathrm{~min}$. and weighed. The values were expressed as mg seedlings ${ }^{-10}$. Vigour index (Abdul-Baki and Anderson, 1973) [8], Vigour index (VI) was computed using the following formula and expressed as whole number.VI $=$ Germination percentage $\mathrm{x}$ Seedling length $(\mathrm{cm})$. The data obtained from experiments were analyzed by the ' $F$ ' test for significance following the method Factorial Completely Randomized Design as described by Panse and Sukhatme. 1985.[9]. Wherever necessary, the percent values were transformed to angular (Arc-sine) values before analysis. The critical differences (CD) were calculated at 5 per cent probability level. The data were tested for statistical significance.

\section{Results:}

The results of table 1 were followed. The highest moisture content (\%) was recorded at 5 DAA (83.1\%) which declined during subsequent stages and attained 12.7 per cent at 40 DAA. For 1000 seed weight (mg),the highest 1000 seed weight was recorded at 15 DAA $(142 \mathrm{mg})$ which declined during subsequent stages and attained $123 \mathrm{mg}$ at 40 DAA. Germination percentage in developing seed, initiated germination from $15 \mathrm{DAA}(7 \%)$ which attained the maximum of 86 per cent at 35 DAA. Thereafter it decreased to 69 per cent on 40 DAA. The seedling length increased significantly with stages of maturity from $1.5 \mathrm{~cm}$ to $2.3 \mathrm{~cm}$ from 15 DAA to 35 DAA and decreased to $2 \mathrm{~cm}$ at 40 DAA. The dry matter production of the seedlings was the maximum at 35 DAA $(1.23 \mathrm{mg})$ which were on par with 40 DAA $(1.2 \mathrm{mg})$. Highest vigour index value of 198 was recorded at 35 DAA, which decreased to 138 in 40 DAA.

\section{Discussion:}

In seed production, the time of harvest is a critical factor determining the seed yield and quality. The unevenness of the performance of a seed lot is due to the differential condition of the mature plant and the environment interaction, which affects seed development.

Seed maturation refers to the physiological and functional changes that occur from time of anthesis until the seeds are ready for harvest. Studies on the pattern of seed development and assessment on time and indices of maturity have greater practical utility on production of quality seeds. Malarkodi and Srimathi (2007) [10] found that stages, symptoms and days for seed development and maturation vary with crops and studies on seed maturation are warranted not only for individual species but also for various locations. According to Harrington (1972) [11], physiological maturity is the stage at which the seed reaches its maximum dry weight and nutrient flow into the seed from mother plant is ceased due to breakage of vascular connection by the formation of abscission layer (Eastin et al., 1973) [12]. In the present study, the pattern of seed development and maturation in davana was traced out to fix the optimum time and indices of physiological maturity for harvesting quality seeds.

The rapid seed growth after fertilization to 5 DAA might be due to more uptake of water, nutrients and also accumulation of photosynthates from source to sink (Patel et al., 1977) [13] which increases with maturity, recording the highest fresh weight at 20 DAA. Venudevan (2008) [14] in glory lily also observed similar growth pattern in orthodox group of medicinal plants. The fresh weight of seed attained their maximum at 18 DAA and decreased thereafter due to disintegration occurred between source to sink and depletion of moisture content from seed. But, (Delouche, 1973; Rao and Rao 1975) [6 \&15] opined that reduction in weight is also due to the depletion of volatile substances in semi fluid state that might have escaped along with water. Similar reductions in weight due to desiccation drying that is specific to orthodox species was also reported in Phyllanthus niruri (Revathi, 2001) [16] and Ocimum (Swapna, 2003) [17], the medicinal plants of tropical region. 
The present study also indicated that the moisture content of seeds were maximum (83.1\%) at 5 DAA and decreased rapidly up to 40 DAA $(12.7 \%$ seed). The loss of water during maturation is considered as inherent phase of development (McIIrath et al., 1963) [18] and its decrease beyond 40 DAA might be due to desiccation and dehydration as opined by Abdul-Baki and Anderson (1973) [8] that is common to all tropical crops. Similar reduction in moisture even after physiological maturation was also reported by Kalavathi (1996) [19] in Cassia angustifolia, Catharanthus roseus and Hibiscus sabdarrifa.

Germination capacity is an indicator of seed maturation and in davana, the seeds collected between 5 and 10 DAA failed to germinate due to immaturity of the embryo, while the seeds collected at 15 DAA attained germinability to a minimum of 15 per cent, which steadily increased to the maximum of 86 per cent at 35 DAA, but decreased to 69 per cent with advances in maturation (40 DAA) based on normal seedling count. The maximization of germination at 35 DAA might be due to attainment of potentiality for reproduction as spelt through mature embryo with essential structures and activation of the enzymes and nutrients required for regeneration of miniature plant). The increasing trend in germination percentage during the development stages which attained the maximum on 35 days after anthesis might be attributed to the maximum dry matter content in seeds (Plate 1).

Woodstock and Combs (1964) [20] expressed seedling length as measures of seedling vigour that aided the expression of their performance under given environmental conditions. The growth of seedlings in the present study increased with advances in maturation and were the maximum at 35 DAA, which was in coincidence with stages of dry weight of seed and seed germination The similar results were obtained to Swapna (2003) [17] in Ocimum and Manimohan (2008) [21] in Kalmegh. The seed vigour which is another parameter was in increasing order attained maximum vigour on 35 DAA (197.8) due to accumulation of higher quantum of dry weight in seed till it reaches the maximum on 35 DAA (1.23 mg) (Fig.1). Heydecker (1972) [22] opined seed vigour as an inherent ability to survive well under wide range of conditions. The computed vigour index value was also the maximum at 35 days after anthesis coinciding with the higher germination and seedling length. Since the vigour index was the product of these two parameters, it was highest at 35 days after anthesis and this is in conformity with findings of Vakeswaran (2001) [23] in Ashwagandha and Gunasekaran (2003) [24] in Solanum nigrum. Thereafter drymatter production decreased slightly due to development of inbuilt mechanism involved in the disorganization of cell organelles within a few days after physiological maturity as reported by Mathews (1973) [25].

From this study, it is inferred that the physiological maturity of davana seeds was attained on $35^{\text {th }}$ day after anthesis, where in germination, seedling length, vigour and dry matter production were higher.

\section{Conclusion:}

The bulk davana crop was raised in the field. Individual flower heads were tagged at the time of flower opening. The seeds were collected at 5 days intervals and subjected to the following seed quality assessment. Seed moisture content, 1000 seed weight, Germination percentage, seedling length, drymatter production and vigour index are the observations recorded. Studies on tracing the pattern of seed development and maturation through physical and physiological characters indicated that the seeds attained physiological maturation on 35 DAA with maximum of dry weight $(129 \mathrm{mg})$, germination $(86 \%)$ and vigour index (197.8).

\section{References:}

[1]. Narayana,M.R., M.N.A.Khan and B.P.Dimri. Davana and its cultivation in India, Farm Bull., No.12, CIMAP,Lucknow,11: 1998 ,110.

[2]. Pisana,R.C. Flavour and extract manufactures association of the united states report.11th International congress of essential oils, fragrances and flavours. New Delhi, India. 1989, pp.157.

[3]. Al-Harbi,M.M., S.Qureshi, M.M.Ahmed, M.Riza, G.A. and A.H.Shah. Studies on the Anti-inflammatory antipyretic and analgestic activities of santanonin. The Jap J.Pharmacol. 64(3): 1994,135-139

[4]. Austin, R.B. 1972. Effects of environment before harvesting on viability. In: Viability of seeds (ed. E.H. Roberts), Chapman and Hall, London, pp. 114-149.

[5]. Bewley, J.D. and M. Black. 1994. Physiology and biochemistry of seeds in relation to germination. Vol. 2. Springer - Verlag. Berlin. pp. 77-94.

[6]. Delouche, J.C. 1973. Seed maturation. In: Seed production manual. NSC and Rock feller Foundation, pp. 162-165.

[7]. ISTA. International Rules for Seed Testing. Seed Sci. \& Technol., Supplement Rules, 27: 1999, 25-30.

[8]. Abdul-Baki, A.A. and J.D. Anderson. Vigour determination in soybean seed by multiple criteria. Crop Sci., 13: 1973,630-633.

[9]. Panse, V.G. and P.V. Sukhatme. Statistical methods for Agricultural workers. ICAR, Publication, New Delhi: 1985, 327-340.

[10]. Malarkodi, K. and P. Srimathi. 2007. Seed physiological maturity. Int. J. Plt. Sci., 2(1): $222-230$.

[11]. Harrington, J.F. 1972. Seed storage and longevity, In: Seed biology. (Ed: T.T. Kozlowski) Academic Press. New York \& London, pp. 145-245.

[12]. Eastin, J.D., J.H. Hultquist and C.Y. Sullivan. 1973. Physiological maturity in sorghum. Crop Sci., 13: 175-178.

[13]. Patel, J.S., P.J. Sharkey and C.A. Atkins. 1977. Nutrition of developing legume fruit. Plant Physiol., 59: 506-510.

[14]. Venudevan, B. 2008. Seed technological studies in glory lilly. M. Sc.(Ag.) Thesis, Tamil Nadu Agricultural University, Coimbatore. 
[15]. Rao, K.V.M. and G.R. Rao. 1975. Growth respiration and endogenous auxins of developing and germinating seeds of pigeonpea. Seed Res., 3: 1-10.

[16]. Revathi, R. 2001. Seed production, testing and storage studies in Phyllanthus amarus (Schum. \& Thom.). M.Sc. (Ag.) Thesis, Tamil Nadu Agricultural University, Coimbatore.

[17]. Swapna, M. 2003. Tracing seed maturation pattern and development of seed testing procedure for Ocimum spp., M.Sc. (Ag.) Thesis, Tamil Nadu Agricultural University, Coimbatore.

[18]. McIIrath, W.J., Y.P. Abrol and F. Heiligman. 1963. Dehydration of seeds in intact tomato fruits. Science, 142: 1681.

[19]. Kalavathi, D. 1996. Seed production, processing, testing and storage studies in medicinal plants of senna (Cassia angustifolia Vahl), periwinkle (Catharanthus roseus G.Don cv. Roseus) and roselle (Hibiscus sabdariffa Linn.). Ph.D. Thesis, Tamil Nadu Agricultural University, Coimbatore.

[20]. Woodstock, L.W. and M.F. Combs. 1964. A comparison of some possible indices of seedling vigour in corn. Proc. Assoc. Off. Seed Anal., 54: 50-60.

[21]. Manimohan, M. 2008. Seed technological studies in kalmegh (Andrographis paniculata). M.Sc.(Ag.) Thesis, Tamil Nadu Agricultural University, Coimbatore.

[22]. Heydecker, W. 1972. Vigour. In: Viability of seeds (Ed. E.H. Roberts), Chapman and Hall London, pp. 209-252.

[23]. Vakeswaran, V. 2001. Investigations on certain aspects of true seeds and synthetic seed development in Ashwagandha (Withania somnifera Dunal). Ph.D. Thesis, Tamil Nadu Agricultural University, Coimbatore.

[24]. Gunasekaran, S. 2003. Seed development and maturation, extraction methods, germination test and storage in solanum nigrum linn. M.Sc. (Ag.) thesis, Tamil Nadu Agricultural University, Coimbatore.

[25]. Mathews, S. 1973. The effect of time of harvest on the viability and pre-emergence mortality of pea (Pisum sativum L.) seeds in soil. Ann. Appl. Biol., 73(2): 211-219.

Table 1. Developmental variation in physical and physiological characteristics of seed during seed development and maturation

\begin{tabular}{|c|c|c|c|c|c|c|}
\hline $\begin{array}{c}\text { Days After } \\
\text { Anthesis } \\
\text { (DAA) }\end{array}$ & $\begin{array}{l}\text { Moisture } \\
\text { content }(\%)\end{array}$ & $\begin{array}{c}1000 \text { seed } \\
\text { weight }(\mathrm{mg})\end{array}$ & $\begin{array}{c}\text { Germination } \\
(\%)\end{array}$ & $\begin{array}{c}\text { Seedling } \\
\text { length }(\mathrm{cm})\end{array}$ & $\begin{array}{l}\text { Dry matter production } \\
\left(\mathrm{mg} \mathrm{seedlings}^{-10}\right)\end{array}$ & $\begin{array}{l}\text { Vigour } \\
\text { index }\end{array}$ \\
\hline 5 & 83.1 & 126 & - & - & - & - \\
\hline 10 & 75.4 & 139 & - & - & - & - \\
\hline 15 & 63.9 & 142 & $7(15.34)$ & 1.5 & 0.93 & 11 \\
\hline 20 & 51.5 & 140 & $14(21.97)$ & 1.5 & 0.98 & 21 \\
\hline 25 & 42.7 & 137 & $38(38.05)$ & 1.6 & 1.00 & 61 \\
\hline 30 & 28.6 & 132 & $56(48.44)$ & 1.7 & 1.12 & 95 \\
\hline 35 & 20.3 & 129 & $86(68.02)$ & 2.3 & 1.23 & 198 \\
\hline 40 & 12.7 & 123 & $69(56.16)$ & 2.0 & 1.20 & 138 \\
\hline SEd & 1.30 & 3.29 & 1.13 & 0.05 & 0.02 & 2 \\
\hline $\mathrm{CD}(\mathrm{P}=0.05)$ & 2.76 & 6.97 & 2.40 & 0.10 & 0.06 & 5 \\
\hline
\end{tabular}

(Figures in parentheses indicate arc sine transformed values)

Fig.1. Seed development and maturation

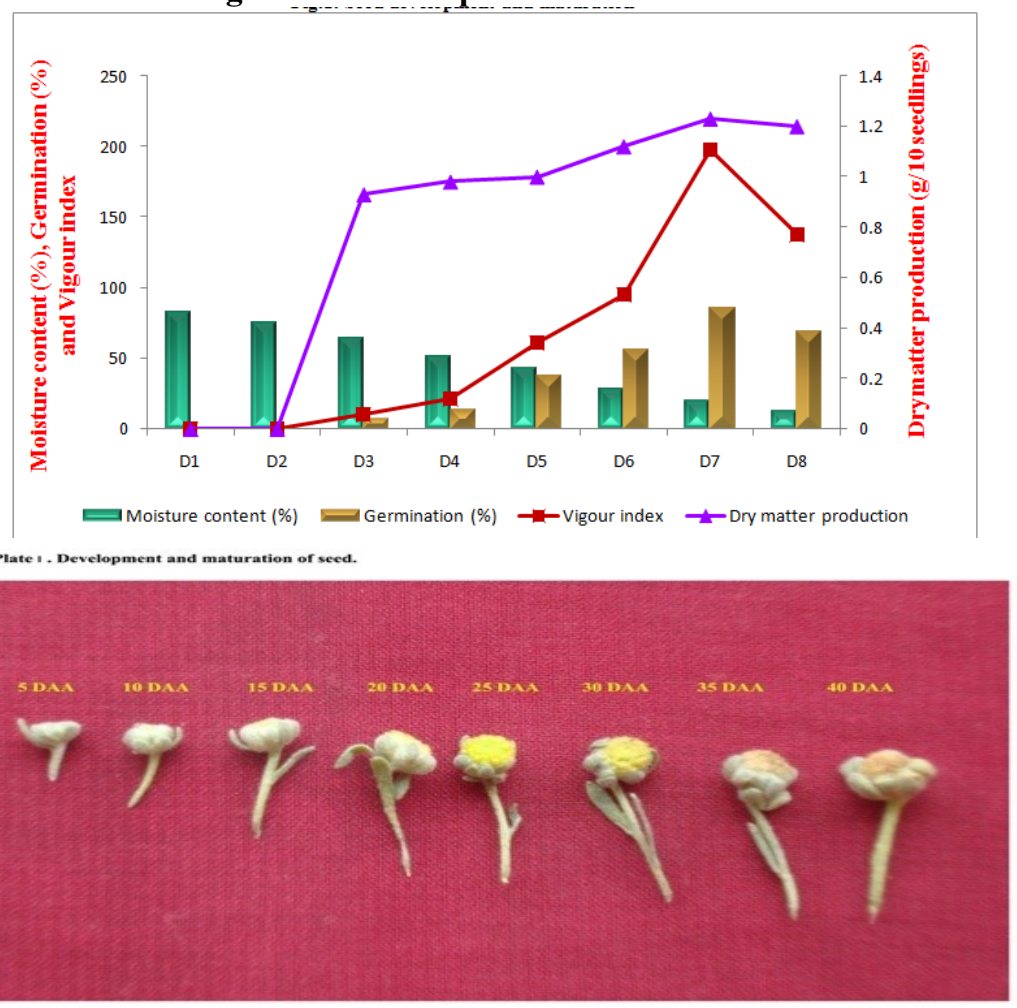

